\title{
MET-overexpressing myxofibrosarcoma frequently exhibit polysomy of chromosome 7 but not MET amplification, especially in high-grade cases: clinical and pathological review of 30 myxofibrosarcoma cases
}

Shirong Ma ${ }^{1+}$, Linni Fan ${ }^{1+}$, Yixiong Liu' ${ }^{1}$, Yingmei Wang ${ }^{1}$, Kangjie Yu², Lifeng Wang ${ }^{3}$, Na Fang ${ }^{4}$, Fang Liu ${ }^{5}$, Shuangping Guo ${ }^{1}$ and Zhe Wang ${ }^{1 *}$

\begin{abstract}
Background: Myxofibrosarcoma (MFS) is one of the most common soft tissue sarcomas. Previous studies have shown that MET protein overexpressed in MFS patients and can serve as a prognostic factor. The reasons for MET protein overexpression include amplification of the MET gene, which is located on chromosome 7q. Triggered by an index case harboring chromosome 7 polysomy rather than MET gene amplification in myxofibrosarcoma, we investigated chromosome 7 polysomy in more cases.

Methods: Immunohistochemistry and fluorescence in situ hybridization (FISH) were performed in 30 MFS cases (including 2 epithelioid variant) to detect the expression of MET protein and gene status.

Results: MET was overexpressed in 14 cases out of 30, while thirteen cases were in higher FNCLCC grades (Grade 2-3). FISH showed that 11 cases having 3 signals on average of Met and more than 3 signals (Mean: 4.6) of centromere $7 q$ (CEP7q). The MET/CEP7 ratio was about 0.65 on average, suggesting that chromosome 7 polysomy, rather than Met gene amplification, leading to the overexpression of MET protein in MFS. MET overexpression and chromosome 7 polysomy are positively correlated with higher Ki-67 index and higher grade and might have a high risk of local recurrence and metastasis.
\end{abstract}

Conclusions: It might reveals another explain of MET overexpression in myxofibrosarcoma, providing a clue for the therapy of MFS.

Keywords: Myxofibrosarcoma, MET, FISH, Chromosome 7 polysomy

\footnotetext{
* Correspondence: zhwang@fmmu.edu.cn

${ }^{\dagger}$ Shirong Ma and Linni Fan contributed equally to this work.

${ }^{1}$ State Key Laboratory of Cancer Biology, Department of Pathology, Xijing

Hospital, Fourth Military Medical University, West Road \#169, Xi'an, Changle

710032, China

Full list of author information is available at the end of the article
}

(c) The Author(s). 2018 Open Access This article is distributed under the terms of the Creative Commons Attribution 4.0 International License (http://creativecommons.org/licenses/by/4.0/), which permits unrestricted use, distribution, and reproduction in any medium, provided you give appropriate credit to the original author(s) and the source, provide a link to the Creative Commons license, and indicate if changes were made. The Creative Commons Public Domain Dedication waiver (http://creativecommons.org/publicdomain/zero/1.0/) applies to the data made available in this article, unless otherwise stated. 


\section{Background}

Myxofibrosarcoma (MFS) is one of the most aggressive types of soft tissue neoplasm. It generally occurs in elderly patients and has a predilection for the limbs. Histologically, MFS features a multinodular growth pattern of spindle to polygonal sarcoma cells within variably myxoid stroma containing long curvilinear vessels [1]. Epithelioid MFS is a rare variant of MFS, accounting for $<3 \%$ of MFS but it is more aggressive than usual high-grade MFS, which has makes up approximately $70 \%$ of local recurrences and $50 \%$ of metastases [2]. In this way, the treatment of MFS is very tricky due to the limited diagnostic and prognostic factors.

MET, a member of the receptor tyrosine kinase family, is encoded by the Met gene on chromosome 7q31, has been found to be overexpressed in many cancers [3-6] and some soft tissue tumors [7-9], including MFS [10]. MET overexpression is usually correlated with tumor progression. Lee et al. found that MET overexpression independently predicts poor survival in MFS patients [10]. Regarding molecular mechanism, MET overexpression is considered attributable to amplification of the Met gene [3, 10-12]. Other studies have shown that polysomy of chromosome 7 can account for the overexpression of MET in chordomas [9] and primary colorectal cancer [13]. In this way, it is not clear whether there is any polysomy in chromosome 7 in MFS. There is also no information available concerning MET expression and gene status in epithelioid variant MFS. In order to further confirm the relationship between MET and MFS, especially the epithelioid variant, we used immunohistochemistry and FISH to detect the MET expression and gene status in $30 \mathrm{MFS}$, including 2 epithelioid variants, and reviewed clinical and pathologic features as well as clinical outcomes.

\section{Methods}

\section{Patients' data}

A total of 30 patients were identified and retrieved from several pathological centers: Xijing Hospital (12 cases, including 1 epithelioid subtype), Xihua Hospital (1 case, epithelioid subtype), Hubei Provincial Cancer Hospital (11 cases), Affiliated Foshan Hospital, Sun Yet-sen University (6 cases). The 30 patients included 16 males and 14 females with a mean age of 56 years (range: 21-87 years) (Table 1). All tumors were graded according to the FNCLCC: 6 cases were classified as grade 1 (Fig. 1a), and 12 cases as grade 2 (Fig. 1b) and the left 12 cases as grade 3 (Fig. 1c). Two cases of grade 3 were epithelioid MFS, showing an infiltrative multinodular growth pattern with alternation of hypercellular and hypocellular myxoid areas. Tumor cells had epithelioid morphology with abundant eosinophilic cytoplasm and oval or plump spindle nuclei, scattered in the myxoid background (Fig. 1d). Here, 15 of the 30 cases were followed up for 7 to 42 months. All the slides were re-examined by two pathologists to ensure correct diagnosis. The specimen collection and study procedures were approved by the Ethics Committee of Xijing Hospital.

\section{MET immunohistochemistry}

Paraffin-embedded sections $4 \mu \mathrm{m}$ in thickness were deparaffinized and treated with $3 \%(\mathrm{v} / \mathrm{v})$ hydrogen peroxide to block endogenous peroxidase activity. They were heated in a microwave for antigen retrieval in $0.01 \mathrm{M}$ citrate buffer at $\mathrm{pH} 6.0$ for $15 \mathrm{~min}$, followed by incubation in $10 \%$ normal goat serum for $30 \mathrm{~min}$ to block the nonspecific antibody-binding sites. The sections were then incubated overnight at $4{ }^{\circ} \mathrm{C}$ with a primary antibody against total MET (1:100, EP1454Y, Abcam). Then a standard rapid EnVision technique (Dako, Glostrup, Denmark) was used to detect the protein conjugates and develop the color. Finally, the sections were counterstained with hematoxylin and visualized. Serial sections were run in parallel with serum in which the primary antibody had been replaced with PBS and rabbit IgG as blank and negative controls, respectively.

MET reactivity was predominantly seen in the cytoplasm and membrane. Immunostaining was evaluated on the basis of the staining intensity (negative, weak, moderate, strong) and the percentage of cells stained, according to the previous studies of MET IHC scoring criteria [11, 14] as follows: 0 (no staining or $<50 \%$ of tumor cells with any intensity), 1+ ( $\geq 50 \%$ of tumor cells with weak or higher staining but $<50 \%$ with moderate or higher intensity), $2+$ ( $\geq 50 \%$ of tumor cells with moderate or higher staining but $<50 \%$ with strong intensity), $3+(\geq 50 \%$ of tumor cells stained with strong intensity), MET overexpression was defined as a score of $2+$ or $3+$. IHC scores were independently evaluated by two pathologists who were blinded to all the cases.

\section{MET fluorescence in situ hybridization}

FISH was performed on formalin-fixed, paraffin-embedded tissue sections in accordance with the manufacturer's instructions. Unstained $4 \mu \mathrm{m}$ sections were placed on electrostatically charged slides and then evaluated using MET (7q31) probe and centromere $7 q$ (CEP7q) dual-color probe (LBP, Guangzhou, China). The hybridized slides were reviewed on an Olympus IX-50 microscope (Olympus, Tokyo, Japan) at $100 \times$ magnification with oil immersion using a DAPI/Green/Red triple band pass filter set. The tissues were scored by evaluating a minimum of 40 tumor nuclei per sample. The amplification of MET 
Table 1 Clinicopathological characteristics of 30 MFS cases

\begin{tabular}{|c|c|c|c|c|c|c|c|c|c|}
\hline Case & $\begin{array}{l}\text { Age } \\
(\geq 56)\end{array}$ & Gender & Location & $\begin{array}{l}\text { Tumor } \\
\text { size }(\mathrm{cm})\end{array}$ & FNCLCC grade & MET expression & $\begin{array}{l}\text { chromosome } \\
7 \text { polysomy }\end{array}$ & $\begin{array}{l}\text { Ki67 } \\
\text { Index } \\
\end{array}$ & Follow-up \\
\hline 1 & Y & $F$ & Left leg & 4.5 & Grade 2 & + & + & $40 \%$ & local recurrence \\
\hline 2 & $N$ & M & Left ischium & 8 & Grade 2 & - & - & $20 \%$ & NED \\
\hline 3 & Y & M & Right shoulder & 2.2 & Grade 2 & - & - & $15 \%$ & NED \\
\hline 4 & Y & F & Left leg & 1.8 & Grade 1 & - & - & $15 \%$ & NED \\
\hline 5 & Y & $\mathrm{F}$ & Right shoulder & 5 & Grade 3 & + & + & $45 \%$ & local recurrence \\
\hline 6 & $N$ & M & Right leg & 1 & Grade 2 & - & - & $15 \%$ & $\begin{array}{l}\text { seven months later, } \\
\text { die of metastasis }\end{array}$ \\
\hline 7 & $N$ & M & Back & 3.5 & Grade 3 & + & + & $30 \%$ & local recurrence \\
\hline 8 & N & $\mathrm{F}$ & Left leg & 3 & Grade 1 & - & - & $3 \%$ & NED \\
\hline 9 & Y & $\mathrm{F}$ & Left scapula & 11 & Grade 3 & + & + & $40 \%$ & $\begin{array}{l}\text { local recurrence and } \\
\text { metastasis to axillary }\end{array}$ \\
\hline 10 & N & M & Right forearm & 4 & Grade 1 & - & - & $5 \%$ & NED \\
\hline 11 & Y & F & Right leg & 1.5 & Grade 1 & - & - & $3 \%$ & NED \\
\hline $12^{*}$ & N & M & Right foot & 1.8 & Grade 1 & - & - & $6 \%$ & NED \\
\hline $13^{*}$ & $N$ & $\mathrm{~F}$ & Ankle & 4 & Grade 2 & + & + & $15 \%$ & $\mathrm{~N} / \mathrm{D}$ \\
\hline 14 & N & $\mathrm{F}$ & Left leg & 21 & Grade 2 & - & - & $40 \%$ & N/D \\
\hline 15 & Y & M & Right armpit & 4.5 & Grade 2 & - & - & $40 \%$ & $\mathrm{~N} / \mathrm{D}$ \\
\hline 16 & $N$ & $\mathrm{~F}$ & Left arm & 1.8 & Grade 1 & + & + & $10 \%$ & $\mathrm{~N} / \mathrm{D}$ \\
\hline 17 & Y & M & Left shoulder & 4 & Grade 2 & + & - & $80 \%$ & $\mathrm{~N} / \mathrm{D}$ \\
\hline 18 & Y & M & Right arm & 4 & Grade 3 & + & + & $70 \%$ & $\mathrm{~N} / \mathrm{D}$ \\
\hline 19 & Y & $\mathrm{F}$ & Right leg & 19 & Grade 3 & + & + & $20 \%$ & N/D \\
\hline 20 & $N$ & M & Left leg & 7.5 & Grade 3 & + & - & $70 \%$ & $\mathrm{~N} / \mathrm{D}$ \\
\hline 21 & Y & M & Right chest wall & 19 & Grade 2 & - & - & $60 \%$ & N/D \\
\hline 22 & $N$ & M & Right chest wall & 1.5 & Grade 2 & - & - & $60 \%$ & $\mathrm{~N} / \mathrm{D}$ \\
\hline 23 & Y & M & Left arm & 11 & Grade 3 & + & + & $70 \%$ & local recurrence \\
\hline 24 & Y & M & Left leg & 13 & Grade 3 & - & - & $60 \%$ & N/D \\
\hline 25 & Y & M & Right arm & 6 & Grade 3 & + & + & $40 \%$ & $N / D$ \\
\hline 26 & $N$ & $\mathrm{~F}$ & Left shoulder & 11 & Grade 3 & - & - & $50 \%$ & local recurrence \\
\hline 27 & Y & $\mathrm{F}$ & Right leg & 9 & Grade 3 & + & + & $20 \%$ & N/D \\
\hline 28 & Y & $\mathrm{F}$ & Right leg & 9 & Grade 2 & - & - & $60 \%$ & $\mathrm{~N} / \mathrm{D}$ \\
\hline 29 & Y & M & Left leg & 2 & Grade 2 & - & - & $40 \%$ & local recurrence \\
\hline 30 & Y & $\mathrm{F}$ & Neck & 3.5 & Grade 3 & + & - & $40 \%$ & N/D \\
\hline
\end{tabular}

*: epithelioid variant $N E D$ no evidence of disease. $N / D$ not done

was defined as $2 \leqq \mathrm{MET}$ gene (red)/CEP7q (green) per cell on average. We defined polysomy of chromosome 7 as three or more signals on average of CEP7 (green) per cell $[9,13]$. To avoid false-positive results originating from the nuclear truncation that occurs in a subset of cells in paraffin-embedded samples, we excluded overlapping cells that did not clearly have separate nuclei from the current analysis.

\section{Statistics}

Statistical analyses were performed using the Statistical Program for Social Sciences (SPSS) software (Version 17.0, SPSS Inc., Chicago, IL, U.S.). Chi-square tests were used to assess the differences and correlations between the expression of MET and the clinicopathological features of patients. Both univariate and multivariate survival analyses were performed. The survival analysis was performed using the Kaplan-Meier method. All tests were two-sided. $P$-values $<0.05$ were considered significant.

\section{Results}

MET overexpression and chromosome 7 polysomy are preferentially detected in higher FNCLCC grade MFS and the epithelioid variant

For immunohistochemistry, MET overexpression was observed in 14 cases (including 1 case of epithelioid 


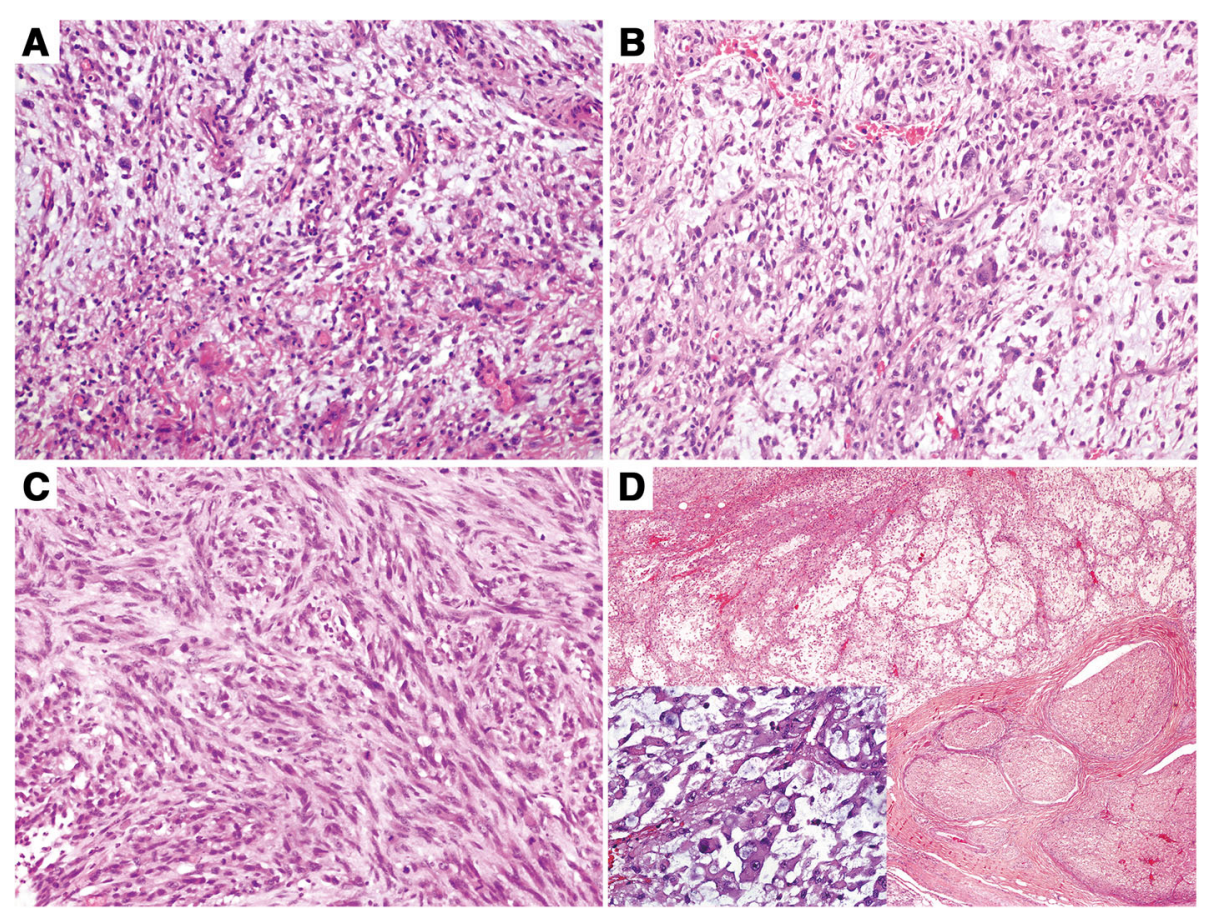

Fig. 1 Mophology of MFS: Spindle to polygonal sarcoma cells within variably myxoid stroma containing long curvilinear vessels. a: FNCLCC Grade 1 MFS; b: FNCLCC Grade 2 MFS; c: FNCLCC Grade 3 MFS; d: Epithelioid variant of MFS, tumor cells is an infiltrative multinodular growth pattern, with alternation of hypercellular and hypocellular myxoid areas. Tumor cells had epithelioid morphology with abundant eosinophilic cytoplasm and oval or plump spindle nuclei, scattered in the myxoid background (inset).

variant) of 30 cases $(46.7 \%$, Table 1$)$, which consisted of 6 males and 8 females with a median age of 61 years (range, 38-87 years). Moreover, the positivity varied with tumor grade, and the positive cases were 1,3 and 10 cases for grade 1 to 3, respectively (Fig. 2a, b), one of which was high grade epithelioid myxofibrosarcoma (Fig. 2c). Other MET-negative cases were of lower grade (Fig. 2d).

We further examined MET gene status using FISH with the probe MET/CEP7. There were also 11 cases with 3 signals on average of MET and more than 3 signals (4.6 signals on average) of CEP7. However, the MET/CEP7 was about 0.65 on average. This is suggested that chromosome 7 polysomy, rather than MET amplification, led to the overexpression of MET protein. Among the 11 cases, chromosome 7 polysomy was preferentially detected in cases with higher FNCLCC grade, for 2 of the 11 cases that were classified as grade 2 (Fig. $3 \mathrm{a}$ ), and the other 8 cases that were classified as grade 3 (Fig. $3 b$ ), including one epithelioid variant (Fig. 3c). In contrast, most of the negative cases had lower FNCLCC grade (Fig. 3d).

\section{MET overexpression and chromosome 7 polysomy are positively correlated with higher FNCLCC grade and higher Ki-67 index.}

As shown in Table 2 and Figs. 2 and 3, MET overexpression and chromosome 7 polysomy were statistically positively correlated with higher FNCLCC grade $(P=0.004$, $P=0.021)$. In contrast, MET overexpression and chromosome 7 polysomy were almost absent from grade 1 tumors in our study. The 11 positive cases were also positively correlated with higher mitotic rate $(P=0.029)$, but it was not related to age, gender, or location.

\section{Clinical outcome}

Except for one censored case, 15 patients were followed up for survival. One patient died of metastasis seven months after surgery. There were 7 cases had local recurrence, of which one had metastasis to axillary (Table 1). Among the 15 follow up cases, there were 5 cases positive for MET overexpression and chromosome 7 polysomy, and this correlation was statistically significant $(P=0.010)$, which indicated that MFS patients with MET overexpression or chromosome 7 polysomy might have a high risk of local recurrence and metastasis. However, Log-rank test showed there to be no significant relationship between MET overexpression and chromosome 7 polysomy patients and the survival time of MFS patients after surgery $(P=0.317)$.

\section{Discussion}

MFS is one of the most aggressive types of soft tissue neoplasm. MFS generally occur in elderly patients and has a predilection for the limbs. Clinically, MFS is tend 


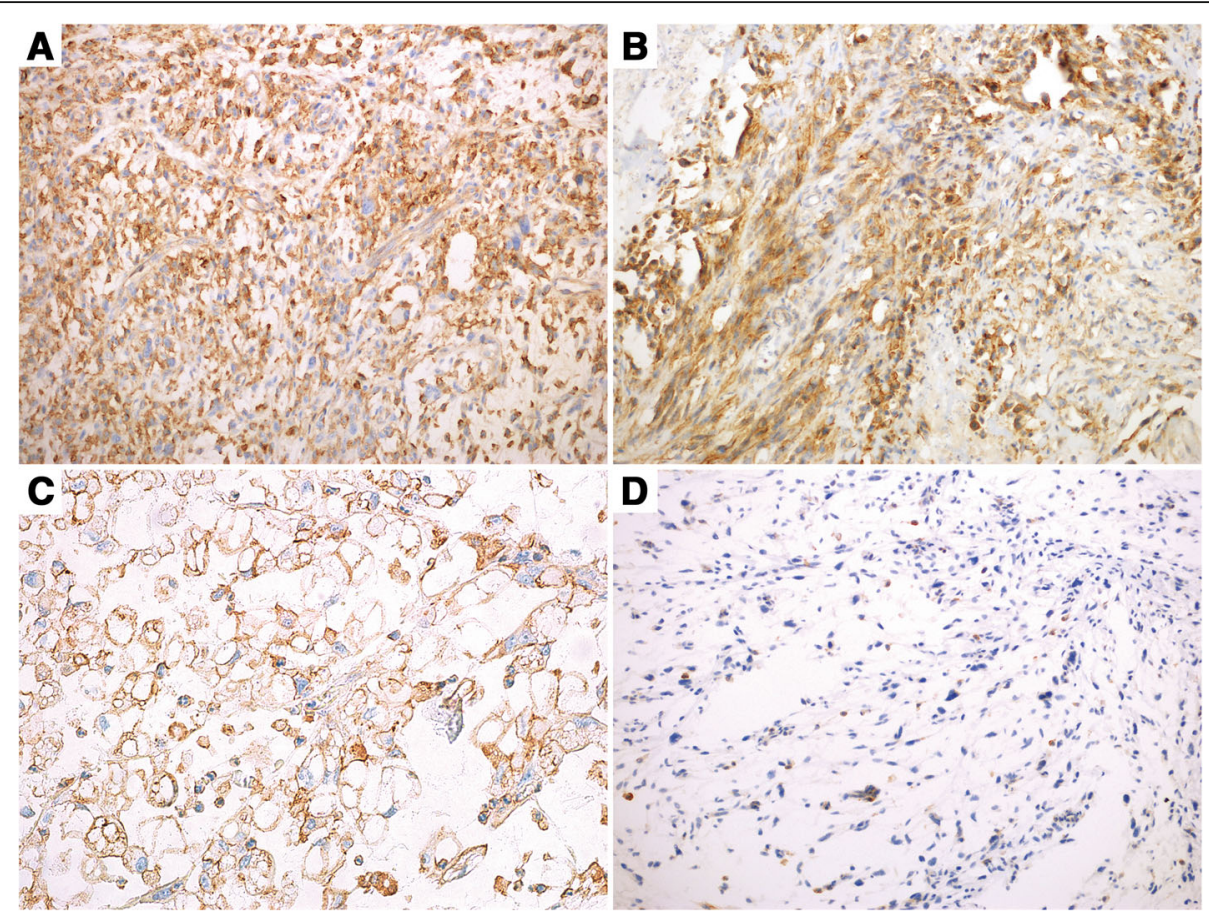

Fig. 2 MET immunostain shows positive cytoplasm staining in the FNCLCC Grade 2 (a), Grade 3 (b), and Epthelioid MFS (c), while negative expression in FNCLCC Grade 1 MFS (d)
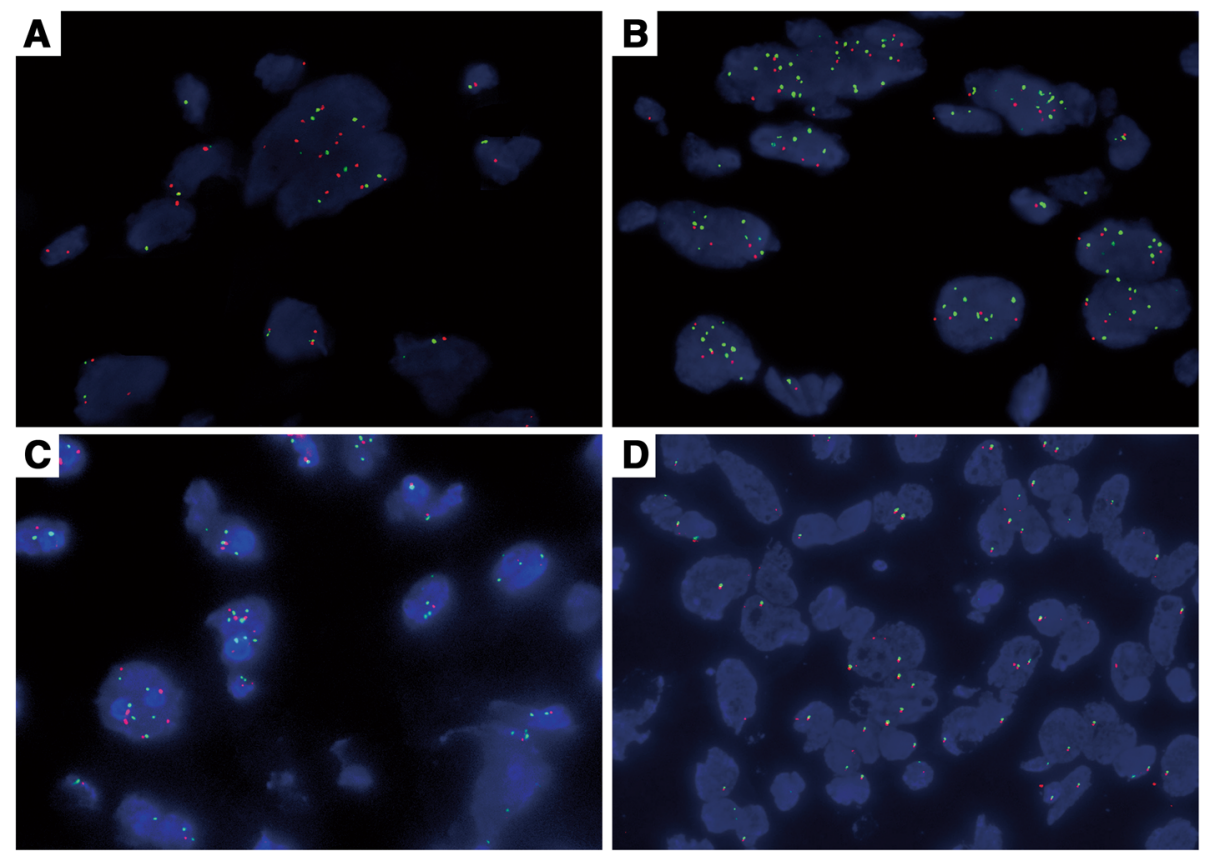

Fig. 3 FISH examination of met gene status by MET (red)/CEP 7(green). Chromosome 7 polysomy, rather than MET amplification, was found in FNCLCC Grade 2 cases (a), Grade 3 cases (b), and epithelioid variant (c). Lower FNCLCC grade cases are usually negative for either MET amplification or chromosome 7 polysomy (d) 
Table 2 Clinicopathological characteristics and associations with MET immunoexpression and chrosome 7 polysomy in 30 MFS

\begin{tabular}{|c|c|c|c|c|c|c|}
\hline \multirow[t]{2}{*}{ Parameters } & \multicolumn{2}{|c|}{$\begin{array}{l}\text { C-MET } \\
\text { expression }\end{array}$} & \multirow[t]{2}{*}{$P$} & \multicolumn{2}{|c|}{$\begin{array}{l}\text { (CEP7 } \\
\text { polysomy) }\end{array}$} & \multirow[t]{2}{*}{$P$} \\
\hline & + & - & & + & - & \\
\hline$\overline{\text { Age }}$ & & & 0.232 & & & 0.757 \\
\hline$\geq 56$ & 10 & 8 & & 7 & 11 & \\
\hline$<56$ & 4 & 8 & & 4 & 8 & \\
\hline Gender & & & 0.282 & & & 0.156 \\
\hline Male & 6 & 10 & & 4 & 12 & \\
\hline Female & 8 & 6 & & 7 & 7 & \\
\hline Tumor size & & & 0.812 & & & 0.892 \\
\hline$\geq 6.7$ & 5 & 6 & & 4 & 7 & \\
\hline$<6.7$ & 9 & 9 & & 7 & 11 & \\
\hline Location & & & 0.765 & & & 0.757 \\
\hline limbs & 8 & 10 & & 7 & 11 & \\
\hline other & 6 & 6 & & 4 & 8 & \\
\hline FNCLCC grade & & & 0.004 & & & $0.021^{*}$ \\
\hline Grade 1 & 1 & 5 & & 1 & 5 & \\
\hline Grade 2 & 3 & 9 & & 2 & 10 & \\
\hline Grade 3 & 10 & 2 & & 8 & 4 & \\
\hline Ki-67 Index & & & 0.011 & & & $0.029^{*}$ \\
\hline$\geq 0.33$ & 10 & 4 & & 8 & 6 & \\
\hline$<0.33$ & 4 & 12 & & 3 & 13 & \\
\hline Local recurrence and metastasis $^{a}$ & & & 0.010 & & & $0.010^{*}$ \\
\hline Yes & 5 & 3 & & 5 & 3 & \\
\hline No & 0 & 7 & & 0 & 7 & \\
\hline
\end{tabular}

to recur persistently, even after wide resection [15-18]. According to the previous studies, local recurrence rates of MFS have ranged from 22 to $79 \%$. Moreover, about one third of locally recurrent MFS cases could progress to a higher grade, and $20-35 \%$ of the high grade neoplasm may develop hematogenous metastases [19-21]. In our study, 18 out of 30 patients $(60 \%)$ had the tumors in their limbs. For followed-up study, 8 out of 15 cases (53.3\%) had recurrence and 2 cases had metastasis. Moreover, one patient died of metastasis seven months after surgery. All 8 recurrent cases were of higher FNCLCC grade (grade 2-3). All these findings were consistent with previous studies. However, the mean age of the patients in our study was 56 years, which was younger than that of previous studies 60 years.

There have been relatively few studies of cytogenetic and molecular genetics of MFS. Willems et al. proposed the concept of progression of MFS as a multistep genetic process ruled by genetic instability. It has been reported that MFS harbors complex karyotypes but without specific structural aberrations. Chromosome 7 is involved in the only recurrent gain [22, 23]. The Met gene, mapped to chromosome $7 \mathrm{q}$, encodes a proto-oncogene, regulating both cell motility and cell growth to allow stem cells and progenitor cells to grow invasively [24]. The gene has been shown to be over-expressed in many tumors, including ovarian [25], lung [26], gastric [27], and colon cancers [13]. Its overexpression usually correlated with a poor prognosis [10].

In our study, immunohistochemical results indicated that MET was over-expressed in 14 out of 30 MFS cases, especially in cases with higher FNCLCC grades and the epithelioid variant $(P=0.004)$. MET overexpression is also positively correlated with higher Ki-67 index $(P=0.011)$. However, there was no relationship with age, gender, nor tumor location in MFS patients. Also, MET overexpression usually predicted high risk of local recurrence and metastasis $(P=0.010)$. These results were consistent with those reported by Lee [10], which showed that MET is expressed in most MFS cases and its overexpression is closely related to deep location, higher grade, and more advanced stage. However, we did not find any prognostic implication of MET due to the limited follow-up data.

$M e t$, also known as hepatocyte growth factor receptor (HGFR), is reported to be a tyrosine kinase receptor in epithelial cells. Through combination with HGF, Met could activate RAS-MAPK or PI3K-Akt signaling pathway to promote cell motility and proliferation [28]. MET is deregulated in many types of human malignancies, including cancers of the kidney, liver, stomach, breast, brain, bone, and blood. Also, abnormal MET activation in cancer correlates with poor prognosis, where aberrantly active MET triggers tumor growth, angiogenesis and metastasis. Due to its oncogenic features, several MET inhibitors have been used to treat cancers in clinical trials. Oral S49076, a unique MET/AXL/FGFR inhibitor, has been used in advanced solid tumors. Another MET inhibitor Crizotinib could prevent peritoneal dissemination in pancreatic cancer. Thus, assessment of the expression and gene status of MET, could be helpful for the potential target therapy for MFS patients.

In previous studies, MET overexpression is considered the result of $M E T$ gene amplification. For this reason, we also tested the MET gene status by FISH with the probe MET/CEP7, and the results showed that five cases which have 3 signals on average of $M E T$ but more than 3 signals (4.6 signals on average) of CEP7. The MET/CEP7 was about 0.65 on average, suggesting that chromosome 7 polysomy, rather than $M E T$ gene amplification, led to overexpression of MET protein in MFS. However, the mechanisms underlying the action of chromosome 7 polysomy in MFS need further study. 


\section{Conclusions}

Our work confirmed that MET overexpression was more frequently found in high grade MFS and the epithelioid variant. Chromosome 7 polysomy, rather than $M E T$ gene regional amplification, might account for the overexpression of MET protein in MFS, which could shed a light on the therapies for MFS.

\section{Abbreviations}

CEP7: centromere 7q; FISH: fluorescence in situ hybridization;

HGFR: hepatocyte growth factor receptor; MFS: myxofibrosarcoma

\section{Funding}

This work was supported by National Natural Science Foundation of China (grant numbers 81472402, 81272651 and 81570180).

\section{Availability of data and materials}

Please contact author for data requests.

\section{Authors' contributions}

SM and LF drafted the manuscript and performed the statistical analysis. YL carried out FISH. YM carried out immunohistochemistry. KY helped to do the follow-up study. LW, NF and FL helped to collect the cases and confirm the diagnosis of the samples. ZW and SG conceived the study, and participated in its design and coordination and helped to draft the manuscript. All authors read and approved the manuscript.

\section{Ethics approval and consent to participate}

The study procedures were approved by the Ethics Committee of Xijing Hospital (reference numbe: KY-20171981). No consent was needed.

\section{Consent for publication}

Not applicable.

\section{Competing interests}

The authors declare that they have no competing interests.

\section{Publisher's Note}

Springer Nature remains neutral with regard to jurisdictional claims in published maps and institutional affiliations.

\section{Author details}

${ }^{1}$ State Key Laboratory of Cancer Biology, Department of Pathology, Xijing Hospital, Fourth Military Medical University, West Road \#169, Xi'an, Changle 710032, China. ${ }^{2}$ Student Team 1, Class 3 Fourth Military Medical University West Road \#169, Xi'an, Changle 710032, China. ${ }^{3}$ Department of Pathology Xinhua Hospital Affiliated to Shanghai Jiao Tong University School of Medicine, Kongjiang Road \#1665, Shanghai 200092, China. ${ }^{4}$ Department of Pathology, Hubei Provincial Cancer hospital, Zhuodaoquan South Road \#116, Wuhan 430079, China. ${ }^{5}$ Department of Pathology, Affiliated Foshan hospital, Sun Yet-sen University, Lingnan North Road\#81, Foshan 528000, China.

Received: 26 February 2018 Accepted: 30 July 2018

Published online: 21 August 2018

\section{References}

1. Look Hong NJ, Hornicek FJ, Raskin KA, Yoon SS, Szymonifka J, Yeap B, et al. Prognostic factors and outcomes of patients with myxofibrosarcoma. Ann Surg Oncol. 2013;20(1):80-6.

2. Nascimento AF, Bertoni F, Fletcher CD. Epithelioid variant of myxofibrosarcoma: expanding the clinicomorphologic spectrum of myxofibrosarcoma in a series of 17 cases. Am J Surg Pathol. 2007;31(1):99-105

3. Yang Y, Wu N, Shen J, Teixido C, Sun X, Lin Z, et al. MET overexpression and amplification define a distinct molecular subgroup for targeted therapies in gastric cancer. Gastric Cancer. 2015;

4. Paliga A, Marginean H, Tessier-Cloutier B, Purgina B, Jonker D, Marginean EC. The Prognostic Significance of c-MET and EGFR Overexpression in Resected Gastric Adenocarcinomas. American journal of clinical oncology. 2015;
5. Refaat T, Donnelly ED, Sachdev S, Parimi V, El Achy S, Dalal P, et al. C-met overexpression in cervical Cancer, a prognostic factor and a potential molecular therapeutic target. Am J Clin Oncol. 2015;

6. Abou-Bakr AA, Elbasmi A. C-MET overexpression as a prognostic biomarker in colorectal adenocarcinoma. The Gulf journal of oncology. 2013;1(14):28-34.

7. Chen Y, Takita J, Mizuguchi M, Tanaka K, Ida K, Koh K, et al. Mutation and expression analyses of the MET and CDKN2A genes in rhabdomyosarcoma with emphasis on MET overexpression. Genes, chromosomes \& cancer. 2007;46(4):348-58

8. Patane S, Avnet S, Coltella N, Costa B, Sponza S, Olivero M, et al. MET overexpression turns human primary osteoblasts into osteosarcomas. Cancer Res. 2006;66(9):4750-7.

9. Grabellus F, Konik MJ, Worm K, Sheu SY, van de Nes JA, Bauer S, et al. MET overexpressing chordomas frequently exhibit polysomy of chromosome 7 but no MET activation through sarcoma-specific gene fusions. Tumour Biol. 2010:31(3):157-63.

10. Lee JC, Li CF, Fang FM, Wang JW, Jeng YM, Yu SC, et al. Prognostic implication of MET overexpression in myxofibrosarcomas: an integrative array comparative genomic hybridization, real-time quantitative PCR, immunoblotting, and immunohistochemical analysis. Mod Pathol. 2010; 23(10):1379-92.

11. Li Y, Li W, He Q, Xu Y, Ren X, Tang $X$, et al. Prognostic value of MET protein overexpression and gene amplification in locoregionally advanced nasopharyngeal carcinoma. Oncotarget. 2015;6(15):13309-19.

12. Park S, Choi YL, Sung CO, An J, Seo J, Ahn MJ, et al. High MET copy number and MET overexpression: poor outcome in non-small cell lung cancer patients. Histol Histopathol. 2012;27(2):197-207.

13. Seo AN, Park KU, Choe G, Kim WH, Kim DW, Kang SB, et al. Clinical and prognostic value of MET gene copy number gain and chromosome 7 polysomy in primary colorectal cancer patients. Tumour biol. 2015;

14. Spigel DR, Ervin TJ, Ramlau RA, Daniel DB, Goldschmidt JH Jr, Blumenschein GR Jr, et al. Randomized phase II trial of Onartuzumab in combination with erlotinib in patients with advanced non-small-cell lung cancer. J Clin Oncol. 2013;31(32):4105-14.

15. Fletcher CD. BJAHPCea: WHO classification of tumors of soft tissue and bone. Lyon: IARC Press; 2013.

16. Castronovo C, Arrese JE, Quatresooz P, Nikkels AF. Myxofibrosarcoma: a diagnostic pitfall. Rare tumors. 2013;5(2):60-1.

17. Mutter RW, Singer S, Zhang Z, Brennan MF, Alektiar KM. The enigma of myxofibrosarcoma of the extremity. Cancer. 2012;118(2):518-27.

18. Sanfilippo R, Miceli R, Grosso F, Fiore M, Puma E, Pennacchioli E, et al. Myxofibrosarcoma: prognostic factors and survival in a series of patients treated at a single institution. Ann Surg Oncol. 2011;18(3):720-5.

19. Kikuta K, Kubota D, Yoshida A, Suzuki Y, Morioka H, Toyama Y, et al. An analysis of factors related to recurrence of myxofibrosarcoma. Jpn J Clin Oncol. 2013:43(11):1093-104.

20. Riouallon G, Larousserie F, Pluot E, Anract P. Superficial myxofibrosarcoma: assessment of recurrence risk according to the surgical margin following resection. A series of 21 patients. Orthop Traumatol Surg Res. 2013;99(4):473-7.

21. Haglund KE, Raut CP, Nascimento AF, Wang Q, George S, Baldini EH. Recurrence patterns and survival for patients with intermediate- and highgrade myxofibrosarcoma. Int J Radiat Oncol Biol Phys. 2012:82(1):361-7.

22. Willems SM, Debiec-Rychter M, Szuhai K, Hogendoorn PC, Sciot R. Local recurrence of myxofibrosarcoma is associated with increase in tumour grade and cytogenetic aberrations, suggesting a multistep tumour progression model. Mod Pathol. 2006:19(3):407-16.

23. Willems SM, Mohseny AB, Balog C, Sewrajsing R, Briaire-de Bruijn $\| H_{\text {, }}$ Knijnenburg J, et al. Cellular/intramuscular myxoma and grade I myxofibrosarcoma are characterized by distinct genetic alterations and specific composition of their extracellular matrix. J Cell Mol Med. 2009; 13(7):1291-301.

24. Glukhova L, Lavialle C, Fauvet D, Chudoba I, Danglot G, Angevin E, et al. Mapping of the 7q31 subregion common to the small chromosome 7 derivatives from two sporadic papillary renal cell carcinomas: increased copy number and overexpression of the MET proto-oncogene. Oncogene. 2000;19(6):754-61

25. Yamamoto S, Tsuda H, Miyai K, Takano M, Tamai S, Matsubara O. Gene amplification and protein overexpression of MET are common events in ovarian clear-cell adenocarcinoma: their roles in tumor progression and prognostication of the patient. Mod Pathol. 2011;24(8):1146-55. 
26. Buckingham LE, Coon JS, Morrison LE, Jacobson KK, Jewell SS, Kaiser $\mathrm{KA}$, et al. The prognostic value of chromosome 7 polysomy in nonsmall cell lung cancer patients treated with gefitinib. J Thorac Oncol. 2007:2(5):414-22.

27. Ha SY, Lee J, Kang SY, Do IG, Ahn S, Park JO, et al. MET overexpression assessed by new interpretation method predicts gene amplification and poor survival in advanced gastric carcinomas. Mod Pathol. 2013;26(12): 1632-41.

28. Weidner KM, Sachs M, Birchmeier W. The met receptor tyrosine kinase transduces motility, proliferation, and morphogenic signals of scatter factor/ hepatocyte growth factor in epithelial cells. J Cell Biol. 1993;121(1):145-54

Ready to submit your research? Choose BMC and benefit from:

- fast, convenient online submission

- thorough peer review by experienced researchers in your field

- rapid publication on acceptance

- support for research data, including large and complex data types

- gold Open Access which fosters wider collaboration and increased citations

- maximum visibility for your research: over $100 \mathrm{M}$ website views per year

At BMC, research is always in progress.

Learn more biomedcentral.com/submissions 